\title{
Islam under the Rule of Law in Europe: How Consistent Is the Human Rights Test?
}

\author{
Marie-Claire Foblets
}

Department of Law \& Anthropology, Max Planck Institute for Social Anthropology, 06114 Halle, Germany; foblets@eth.mpg.de

\begin{abstract}
This contribution draws attention to human rights as an instrument of justice to deal with requests that are either made directly or may prove indirectly to be relevant to Muslims who claim the protection of freedom of religion and faith in contemporary European societies. The analysis is distributed over two distinct but complementary illustrations of such claims. The position defended here is that the key to a successful multicultural society lies in enabling adherents of all religions and beliefs, and thus also Muslims, to participate to the same extent, fully and actively, in social life, both as citizens and as private individuals. The challenge lies in finding the balance between looking after the interests of the majority society and meeting the needs and wishes of minority groups and communities, including those communities that are perceived to be 'new'.
\end{abstract}

Keywords: human rights; Islam; Europe; boys circumcision; Islamic headscarf; reasonable accommodation

Citation: Foblets, Marie-Claire. 2021. Islam under the Rule of Law in Europe: How Consistent Is the Human Rights Test?. Religions 12 857. https://doi.org/10.3390/ rel12100857

Academic Editors: Silvio Ferrari, Roberta Medda-Windischer and Kerstin Wonisch

Received: 3 August 2021

Accepted: 31 August 2021

Published: 12 October 2021

Publisher's Note: MDPI stays neutral with regard to jurisdictional claims in published maps and institutional affiliations.

Copyright: (C) 2021 by the author. Licensee MDPI, Basel, Switzerland. This article is an open access article distributed under the terms and conditions of the Creative Commons Attribution (CC BY) license (https:/ / creativecommons.org/licenses/by/ $4.0 /)$.

\section{Introduction}

European societies have, in just half a century, become more explicitly multicultural as a result of a number of decisive political and social developments, both within their societies and on an international scale. There is every indication that this trend will continue in the coming years, not least as a consequence of international waves of migration that can appear today to have become a structural feature of globalisation. European welfare states continue to attract newcomers in the hundreds of thousands each year, an increasing number of whom are Muslims. This brings me to the topic that is at the core of this contribution: the ever more prominent presence of Muslim minorities across Europe brings with it new challenges, not least in law: not only legislators but public administrations, judges, school principals, heads of care institutions and employers more generally are also called upon to address the question of the extent to which the law, as it stands, offers the appropriate solution to the claims made by persons who, in concrete situations, expect their religious belief to be taken into account. This question, in turn, raises a number of burning issues. One such issue is the need for decision-makers to gain the necessary knowledge about Islam and about the way this knowledge might prove relevant for ensuring that the legislation and/or policy that applies to them continues to be suitable. Another issue has to do with an important development in this area, namely, the observation that for several years now, there has been an increasing tendency to invoke human rights as a corrective to existing policies and legislation. The question, however, is how structural and sustainable that corrective can be. In some cases, human rights make it possible to create space for religious minorities, while in other cases, they are also accompanied by significant limitations, and it is not always clear why the pendulum swings once in one direction, once in the other.

In this contribution, I draw attention to human rights as an instrument of justice used to deal with requests that are either made directly or may prove indirectly to be relevant to Muslims who claim the protection of their freedom of religion and faith in contemporary European multicultural society. I have broken down my analysis into two distinct but complementary illustrations of such claims. By way of conclusion, I will return to the 
critical question of consistency in the way human rights are put at the service of justice when it comes to the protection of Islam and its believers in Europe.

\section{Human Rights as Guarantor of Minority Protection in Contemporary Multicultural Europe}

Human rights play a central role today in pursuing a balance between, on the one hand, safeguarding individual freedom, including the freedom of religion and belief and, on the other hand, the protection of other basic values that are considered to be a higher priority in a democratic state governed by the rule of law. Such a balance is often difficult to find, as the illustrations below will hopefully show. The illustrations are drawn from case law, domestic as well as international. The illustrations show how difficult it can be for a court to protect values that are claimed to be fundamental and that underlie a democratic society. What should not happen is that protection plays out in a different way depending on which religion is involved: Muslims deserve to feel protected in the same way as are - or are not—other religions and beliefs.

It is the need for consistency that will serve as the common thread through this analysis, which asks the question of whether the law does, in fact, allow much space for individual autonomy when it comes to permitting members of Muslim communities to follow their own norms and values in daily life, in their family lives and, more generally speaking, in those relationships that fall within the broad scope of law. ${ }^{1}$

The position that this contribution seeks to defend is that the key to a successful multicultural society lies in enabling adherents of all religions and beliefs, and thus also Muslims, to participate to the same extent, fully and actively, in social life, both as citizens and as private individuals. This defence of their participation is, of course, not meant to be at the expense of the protection of fundamental principles of a democratic secular state governed by the rule of law. The challenge lies in finding the right balance between looking after the interests of the majority society and meeting the needs and wishes of minority groups and communities, including those communities that are perceived to be 'new' within that society.

\subsection{Two Concrete Illustrations Drawn from Case Law}

In practice, we see that the criterion by which legislators and judges today decide if they can trust individuals to make autonomous decisions about how to organise their lives and which (individual or collective) identity to claim for themselves is not applied uniformly in all situations. In what follows, I will give two illustrations drawn from case law that seem to support this observation. In both cases, different fundamental rights are at stake. The first example has to do with the right of parents to rear their children in their own religion versus the child's right to self-determination. The case concerned a practice that is regarded in both Islam and Judaism to be binding for reasons grounded in belief, namely the circumcision of (minor) boys. I am basing this analysis on a judgment handed down in Germany in 2012, which gave rise to heated public debate in Germany. ${ }^{2}$ The second illustration comes from two judgments by the Court of Justice of the European Union (hereafter the CJEU) that address the right of private employers to ban the wearing of religious signs in the workplace (the principle of neutrality) versus the protection of individual freedom of religion on the part of employees (the Samira Achbita and Anor v. G45 Secure Solutions NV and the Asma Bougnaoui v. Micropole SA judgments dated 14 March 2017). ${ }^{3}$

\subsubsection{Circumcision of Boys: The Free Will of the Child versus the Rights of His Parents}

On 7 May 2012, the Landgericht (Regional Court) of Cologne ruled, on appeal, that circumcising boys for religious reasons constitutes "bodily harm", even if the parents consented. The facts of the case concerned the four-year-old son of Muslim parents who suffered from bleeding a few days after the operation. The professional liability of the doctor was thus engaged. The judge ruled that in that case, the doctor had acted to the best 
of his ability but also made it very clear that the fundamental right of the child to bodily integrity outweighed the fundamental (religious) rights of the parents. Therefore, doctors in Germany began to refuse to perform such procedures, at least until a clear court ruling determined whether religious circumcision of boys could be carried out without being considered an infringement of the physical integrity of minors.

In the debate that followed, there were several views that were highly critical of the court's ruling, coming mainly from the Jewish community in Germany. The Central Council of Jews in Germany spoke of a ' $(\ldots$ ) beispiellosen und dramatischen Eingriff in das Selbsbestimmungsrecht der Religionsgemeinschaft' (an unprecedented and dramatic intervention in the right of the religious community to self-determination) (Frankfurter Allgemeine Zeitung 2012) and did not hesitate to invoke the historical argument that Germans had nothing to teach them about respect for physical integrity. "Circumcision is an integral part of the Jewish faith and has been practised for centuries", remarked Dieter Graumann in his capacity of president of the Council in an interview (Frankfurter Allgemeine Zeitung 2012). ${ }^{4}$ Pinchas Goldschmidt, on behalf of the Conference of European Rabbis (CER), condemned the judgment in no uncertain terms as "a threat for the present and the future of Jewish communities in Germany" (Strack 2012). The reaction of German paediatricians was, however, the diametrical opposite, as they welcomed the position taken by the judge (Kristiansen and Sheikh 2013, p. 345). The stalemate did not last long, however.

On 20 December 2012, the German legislature adopted a compromise: circumcision for religious reasons remains possible but must be carried out professionally, which means, among other things, that everything must be conducted to ensure that the child feels as little pain as possible, and the parents must be informed in advance of the nature and method of the procedure. The operation is to be performed by a doctor unless the child is under the age of six months. Only in the latter case can a qualified and trained person (such as a mohel in the Jewish community) also perform the circumcision. ${ }^{5}$

The German legislative solution can be seen as an interesting example of reasonable accommodation, ${ }^{6}$ not least because it opted for a change in the area of civil law and not for criminalisation. Not everyone agreed with this reasoning, however. For the purposes of this illustration, and in particular as regards the debate about respect for self-determination and the risk of applying a double standard, with stricter criteria for certain religious practices, in this case, the reactions to the publication of the legislative amendment were revealing. ${ }^{7}$ Some commentators spoke of a selective intervention, which used the pretext of protecting the child's bodily integrity mainly to target the parents' freedom of religion (Bodenheimer 2012). ${ }^{8}$ It is incontrovertible that rearing children requires the parents to take all sorts of decisions that have an irreversible impact on the rest of the children's lives. Male circumcision is, furthermore, a medical procedure that in many countries (including the United States) is carried out on young boys not for religious but for hygienic reasons. The outrage at the parents' religious motives for continuing a centuries-old practice, therefore, feeds the suspicion among some that this reaction amounts to a targeted attack on specific minorities. 'The European reluctance to circumcise boys becomes even more apparent when requested for religious or cultural indications', wrote Robert Wheeler and Pat Malone (Wheeler and Malone 2013, pp. 321-22).

The controversy about the German Court's decision of 2012 has now faded away, but one cannot easily conclude that with this, the question has gone away. Selective indignation at certain minority practices elicits annoyance, especially among members of minority groups who feel that they are being targeted; this is all the more so since the protection of religious freedom has historically been rooted in the concern to protect groups and communities against persecution and discrimination. ${ }^{10}$ Some such groups feel that they are the targets of growing displeasure at the presence of certain religious groups in Europe and victims of growing secularisation.

Another minority practice that has for some time now been the subject of a very similar debate in several European countries is the ritual slaughter of animals, a religiously- 
motivated form of slaughter that has come in for increasing criticism in recent years. ${ }^{11}$ On 17 December 2020, the Court of Justice of the European Union, sitting as the Grand Chamber, issued a judgment on this practice. ${ }^{12}$ A Decree of the Flemish Region (Belgium) of 7 July 2017 regarding permitted methods of slaughtering animals univocally prohibits animals from being slaughtered without prior stunning. The decree was challenged by several Jewish and Muslim believers, among others. In their view, the decree infringes European Regulation No 1099/2009 ${ }^{13}$. That regulation requires that, in principle, an animal be stunned prior to being killed, but by way of derogation, it also permits the practice of ritual slaughter in accordance with which an animal may be killed without being stunned.

In its examination of the proportionality of the limitation, the Court holds that the decree allows a fair balance to be struck between the importance attached to animal welfare and the freedom of Jewish and Muslim believers to manifest their religion. In that regard, it states, first, that the obligation to use reversible stunning is appropriate for achieving the objective of promoting animal welfare. Secondly, as regards the necessity of the interference, the Court emphasises that the EU legislature intended to give each Member State broad discretion in light of the need to reconcile the protection of the welfare of animals when they are killed and respect for the freedom to manifest religion. In the view of the Court, a scientific consensus has emerged that prior stunning is the optimal means of reducing the animal's suffering at the time of the killing. Thirdly, as regards the proportionality of that interference, the Court observes, first of all, that the Flemish legislature relied on scientific research and that it sought to give preference to the most up-to-date method of killing that is authorised. Next, the Court also points out that that legislature is part of an evolving societal and legislative context, which is characterised by increasing awareness of the issue of animal welfare. Lastly, the Court finds that the decree neither prohibits nor hinders the putting into circulation of products of animal origin derived from animals which have undergone ritual slaughter, where those products originate in another Member State or in a non-Member State.

In seeking a balance between freedom of religion, guaranteed by Article 10 of the Charter of Fundamental Rights of the European Union, and animal welfare, as set out in Article 13 of the Treaty on the Functioning of the European Union, the Court holds that EU law does not preclude legislation by a Member State which requires, for purposes of ritual slaughter, a reversible stunning procedure which cannot result in the animal's death.

Ritual slaughter concerns not so much the protection of individual autonomy, as is the case with the rights of parents, but rather the autonomy of religious communities. ${ }^{14}$ Yet, a similar critical reflection can be made here on behalf of the associations seeking protection of their freedom of religion and faith. The way the Court assessed the need to promote animal welfare, while also imposing significant limitations on the freedom of religion of Jewish and Muslim communities, gives the latter reason, yet again, to adopt a sceptical attitude: why is there so much outrage about the pain that may be caused by ritual slaughter for a few seconds, but is there no comparable anger at the way in which the food industry treats animals, often on a very large scale, not only when they are killed but since their birth and sometimes even before then?

2.1.2. Code of Conduct in the Workplace: The Freedom to Conduct a Business versus the Freedom of Religious Expression of Individual Employees

Another religious practice that has given rise to much debate in Europe over the past two decades is the Islamic headscarf. ${ }^{15}$ The intention is not to review or summarise that debate here, ${ }^{16}$ but to present a second illustration, in the form of two relatively recent judgments of the Court of Justice of the European Union, of an approach that, from the perspective of the believers who felt concerned, has been interpreted as a confirmation of the reduced autonomy granted to them when it comes to their participation in society, in these cases in the labour market. ${ }^{17}$ 
May a private employer forbid a female employee who professes Islam to wear a headscarf at work? And if the employee refuses to take off her headscarf at work, can she be dismissed? This, in sum, is the question that the CJEU replied to in two-much debatedjudgments handed down on 14 March 2017. ${ }^{18}$ In the first case (Asma Bagnaoui/Micropole SA), the employee had refused to remove her headscarf after one of her employer's clients had complained about her wearing it. In the other case (Achbita/G4S NV), the issue was the following: Samira Achbita started working in February 2003 for G4S, a company that provides security and reception services. In April 2006, Ms Achbita informed her employer that she planned henceforth to wear an Islamic headscarf during working hours. The company's management informed her that wearing a visible sign of political, philosophical or religious beliefs was unacceptable because doing so infringes the neutral image of the company. This—hitherto unwritten—rule was incorporated shortly thereafter (in June 2006) into the company's internal code of conduct. On 12 June 2006, Ms Achbita was dismissed on the grounds of her intention to wear her headscarf during business hours.

The Court held, among other things, that an internal company rule that prohibits the wearing of a visible religious, political or philosophical sign does not as such constitute direct discrimination on the grounds of religion or belief. A rule that applies to all employees and is intended to guarantee the neutral image of a company is not to be considered direct discrimination within the meaning of the European Union's Council Directive 2000/78 on equal treatment in employment and occupation. ${ }^{19}$ Whether such a rule could in time lead to indirect discrimination, whereby persons who profess a certain religion or belief are particularly disadvantaged, is to be determined, according to the European Court, by the national court. In other words, it is up to the referring court to investigate the extent to which the disputed internal company rule meets the three classic requirements when identifying discrimination - in this case, an indirect disadvantage — namely, the question of the objective justification, legitimate aim and whether the means of achieving that aim are appropriate and necessary. In the Achbita case, the Court grounds its ruling on the following considerations: (1) as regards the first condition, namely, a legitimate aim, the CJEU held that the desire by one particular company to display "a policy of political, philosophical or religious neutrality" in relations with customers must, in principle, be considered legitimate. The CJEU made a connection here with the freedom to conduct a business that is recognised in Article 16 of the Charter of Fundamental Rights of the European Union. This legitimacy is not compromised if the decision of the employer, in pursuit of neutrality, "involves only those employees who are presumed to engage in contacts with the employer's customers"; $; 2$ (2) as regards the second condition, namely, the question whether the disputed internal company rule is appropriate, the CJEU held that if such a policy "is genuinely pursued in a consistent and systematic manner", a prohibition against wearing visible signs of political, philosophical or religious beliefs can be appropriate "for the purpose of ensuring that a policy of neutrality is properly applied"; (3) and lastly, as regards whether the internal rule goes further than what is strictly necessary, the CJEU instructs the national courts to determine whether the prohibition in fact applies solely to those company employees who are in direct contact with customers. The national court must also determine whether the inherent constraints to which the company is subject was taken account of; without G4S being required to take on an additional burden, it would have been possible, faced with [the employee's] refusal, to offer her a post not involving any face-to-face contact with customers, instead of dismissing her.

Both judgments met with diametrically opposing reactions. ${ }^{21}$ They were seen positively by those who are persuaded that employers in Europe need the necessary space to prohibit religious and/or philosophical symbols in the workplace if they consider that desirable. ${ }^{22}$ Such space is seen here as an integral part of the freedom to conduct a business. From the perspective of the right to work, however, the judgments were read differently: for the growing number of (mainly female) workers who are actively looking to enter the labour market in Europe today, without assuming that they must compromise their individual religious freedom and its public manifestation in order to do so, the judgments 
represent a limitation to that freedom and, therefore, a step backward in terms of protection of women workers in particular. This weakening of protection can be understood as follows: the Court refers, in point 39, to the judgment of 15 January 2013 in Eweida and others v. The United Kingdom. ${ }^{23}$ Ms Eweida was employed by British Airways as check-in staff and, therefore, was in direct contact with customers. She wore a cross around her neck. That was deemed by her employer to be a breach of the (neutral) dress code with which the company sought to communicate a certain image and brand recognition. The European Court of Human Rights (ECtHR) in Strasbourg ruled in favour of Ms Eweida. It held that in the balancing of interests, while the aim of the employer to project a certain image of itself was legitimate-and on that point, the Strasbourg Court's position coincided with that of the CJEU - it did not consider this as a reason to limit the employee's freedom of religion and belief. In its reasoning, the ECtHR opted explicitly for a contextual approach, with substantial attention to striking a balance between the interests on both sides. ${ }^{24}$

In the Achbita case, the reasoning of the CJEU can be seen as an implicit approval of a policy that private employers may exclude persons who visibly manifest their religion in the workplace (in the present case, through their dress) from a not-insignificant segment of the labour market, that is, where such employees have direct contact with customers. How will such reasoning be read by someone who applies for a job in the private sector? Must such a person henceforth limit herself to applying for jobs where she will not be "visible"? Is such reasoning not to be regarded as the erosion of the individual freedom to manifest one's religious beliefs as soon as this entails some commercial risk? In its approach to the Achbita case, the CJEU did not go into the question of whether the requirement of neutrality, including in dress in the case of female employees, could be imposed as a "genuine and determining professional requirement", to use the words of the Bougnaoui judgment. Had the Court done so, it would have had to justify its position. That would have given the case a very different impact, for if the requirement of neutrality in dress were in fact to be seen as a genuine requirement, then the outcome would have been to give individual freedom far less weight. The freedom of religion and belief is certainly not absolute, and a balancing of interests can and must, therefore, take place, including in matters of employment. Hence, the outcome is not that an employer's commitment to neutrality cannot be one of the factors weighed in the balance. In public service, where the job requires it, as in the case of prosecutors, judges, and court clerks, it has long been considered self-evident that neutrality, including in dress, is a legitimate consideration. For other positions within the public service, we see, for example in the United Kingdom, that some female police officers wear a headscarf, albeit in the colour of the uniform. Reasonable accommodation is thus not to be excluded, including in the public service. In the case of female employees who wish to wear a headscarf at work, the critical question lies in what is to be regarded as a genuine requirement. That issue must be addressed as objectively as possible.

Sales figures are, after all, essential to business, and are, in fact, the conditio sine qua non for creating jobs. Moreover, it is the employers who stand to lose earnings if customers drop off because it bothers them that some staff members manifest their religious beliefs openly and if such employers cannot count on their employees to stop these losses. The CJEU has shown understanding for this problem and, therefore, suggested as a compromise solution that henceforth, employers may decide that visible religious, political or philosophical symbols may be worn only by employees who are not in direct contact with customers. This means, in this case, that Muslim women who wish to wear a headscarf-in line with the freedom of religion and belief-when applying for a job in the private sector face a serious additional restriction, namely that companies, which seek to be "consistent and systematic," as the Court put it, can only be given "back office" jobs if they are to be in compliance with their internal company rules.

Quite apart from the question of how companies can in practice keep their "front office" and "back office" strictly separate-after all, how can an employer apply a staff policy that over the long term would mean that employees initially hired for the "back 
office" would be prevented from advancing sooner or later to jobs that involve direct contact with clients-there is also the important question of why none of the other rights also guaranteed by the European Charter of Fundamental Rights, such as the right to fair and just working conditions, are invoked. How sustainable is such reasoning in the context of an ever more diverse society: on the one hand, a woman is allowed to express her religious beliefs in the workplace, with the understanding that she must also accept that her employment poses a risk to her employer, while on the other hand, the employer is also between a rock and a hard place because he or she cannot afford to lose customers due to their unwillingness to deal with the employee, and thus risk losses (in earnings), and, therefore, opts for a policy that avoids all direct contact between that employee and customers.

It so happens that on 15 July 2021 the Court of Justice of the European Union ruled, once again, on the issue of wearing a headscarf in the workplace. ${ }^{25}$ The Court reiterates the position it took in the rulings handed down on 14 March 2017, namely that the employer's desire to demonstrate neutrality towards (both public and private) customers could be considered a legitimate objective if, in pursuing that objective, the employer only involves employees who have contact with customers.

What is new in this ruling is the specification that the mere desire of the employer to pursue a neutrality policy is not sufficient to objectively justify an indirect distinction based on religion or belief. In view of the Court, to be objective, three conditions require to be met: first, a genuine employer need must be proven, ${ }^{26}$ second, the dress code must be appropriate to ensure the proper application of the neutrality policy, the policy must be effectively pursued in a coherent and systematic manner; and third, the dress code must be proportionate, it may not go beyond what is strictly necessary relative to the detrimental consequences that the employer is trying to avoid through the dress code. These are three welcome clarifications, since in previous judgments the Court had only ruled that external neutrality towards customers could be considered a legitimate objective, and it had not ruled on internal neutrality.

All in all however, in these two recent combined cases relating to employees choosing to wear a headscarf, the European Court of Justice confirmed its previous case law, be it that it now has provided more guidance on how employers can enforce a neutral dress code.

How can we move forward from here? There is every indication that certain questions relating to religious and cultural diversity in society have taken on a particular symbolic value and that this value increases as those questions come under heated debate. A reason that is frequently invoked to justify the prohibition of the Islamic headscarf is the fear that the woman is subject to certain social pressures that restrict her freedom to make her own decisions. Oppression must always be seen, however, in the context of the particular situation before one can judge. A not insignificant group of Muslim women today demand the right to wear a headscarf. ${ }^{27}$ They wish to express their identity in this manner and are not willing to renounce it as a condition for taking an active part in society. Asking them to remain "invisible" because their expression of their religious identity may damage the image of their employer is a reasoning that is not without risk. Reading just a few of the critical reactions to the two CJEU judgments of 14 March 2017 makes this clear. Their tone is comparable to some of the reactions to the judgment of the Court in Cologne discussed above: people feel that their identity is not being granted full recognition. ${ }^{28}$

\section{Conclusion: How Consistent Is the Human Rights Test? A Few Critical Remarks}

This much is certain: in the coming years, the question will arise more and more frequently as to what extent human rights can serve as the ultimate guarantor of the protection of the rights of an increasing number of members of Muslim communities throughout Europe and, by the same token, of social cohesion within contemporary multicultural society. In determining the admissibility under the rule of the domestic jurisdiction of certain (religiously motivated) practices and traditions, the focus is, in practice, strongly 
on the question of how to balance the freedom of religion against other interests and how to keep that balance in a way that is sustainable, not least by ensuring consistency in the approach. If certain groups or communities feel targeted because they cannot avoid the impression that their beliefs or faith-based practices are met with particular scepticism, then a harsh approach loses credibility. Groups and communities, in casu Muslims, feel stigmatised and lose confidence in the rule of law. The above illustrations may be seen as extreme, perhaps, but they reflect reality and can, therefore, be useful warnings against the aforementioned risk.

It is likely that in the future, the question of the boundaries between what falls under the protection of human rights and under what terms the balance of interests at play will be formulated will only grow in importance. This is not least because, for certain minority groups, interest in the question is growing steadily. In an increasing number of situations, they seem to want to provoke debate on these questions, in order that they can in this way take an active part in discussions about their participation in social life and in helping to determine the conditions for such participation. ${ }^{29}$ And it must be perfectly acceptable to do so in a democratic state governed by the rule of law.

European societies will, in the coming years, have to organise themselves increasingly as plural societies. There is no lack of legal instruments with which to give concrete shape to that organisation. However, part of the difficulty arises as a result of the reality of a multicultural society and the fact that the conflicts that inevitably go hand in hand with such a society are ever more numerous and complex, partly because the interests involved revolve in most cases around questions of fundamental rights, and thus touch on essential values. Moreover, they are not limited to any specific domain of social life but involve a broad range of topics that evolve with society. Examples from the recent past show how difficult it is to weigh up the various interests and find the right balance between too much and too little protection.

The importance of these considerations cannot be overemphasised when it comes to the freedom of religion of Muslims throughout Europe; they are a rapidly growing group of the population, and, therefore, what is at stake here is nothing less than the future of European societies and the possibility of achieving a lasting peaceful coexistence among communities, with their diverse cultures and religions.

Funding: This research received no external funding.

Acknowledgments: The author expresses sincere thanks to Gabriele Buchholtz, Johanna CroonGestefeld and Andreas Kerkemeyer for having given her permission to reproduce here a text that draws significantly on the third and fourth parts of a text paper to a collective volume they have edited and that is to be published under the title Integratives Recht (Mohr Siebeck, Tübingen, 2021).

Conflicts of Interest: The author declares no conflict of interests.

\section{Notes}

I have already defended this position in (Foblets 2018).

2 Landgericht Cologne, 7 May 2012, Docket no. 151 Ns 169/11 (for the English translation, see: https://www.dur.ac.uk/ resources/ilm/CircumcisionJudgmentLGCologne7May20121.pdf, accessed on 4 March 2021). For a more developed version of this analysis, see: (Foblets 2016).

3 CJEU 14 March 2017, C-157/15, ECLI:EU:C:2017:203 (Achbita) and CJEU 14 March 2017, C-188/15, ECLI:EU:C:2017:204 (Bougnaoui).

4 For the English translation of the press release issued by the Council, see: http://www.zentralratderjuden.de/en/article/3706 .on-the-decision-of-the-district-court-of-cologne-concerning-circumcision-of-boys.html (accessed on 4 March 2021).

5 The new $\S 1631 \mathrm{~d}$ of the German Civil Code (BGB), introduced by the Law of 20 December 2012, states: "Beschneidung des männliches Kindes: (1) Die Personensorge umfasst auch das Recht, in eine medizinisch nicht erforderliche Beschneidung des nicht einsichts-und urteilfähigen männlichen Kindes einzuwilligen, wenn diese nach den Regeln der ärtzlichen Kunst durchgeführt werden soll. Dies gilt nicht, wenn durch diese Beschneidung auch unter Berücksichtigung ihres Zwecks das Kindeswohl gefährdet wird. (2) In den ersten sechs Monaten nach der Geburt des Kindes dürfen auch von einer Religionsgesellschaft dazu vorgesehene Personen Beschneidungen gemäss Absatz 1 durchführen, wenn sie dafür besonders ausgebildet und, ohne Arzt zu 
sein, für die Durchführung der Beschneidung vergleichbar befähigt sind". http:/ /last-conformer.net/2012/12/28/its-official/ (accessed on 4 March 2021). See among others (Germann 2013; Walter 2012; Isensee 2013; Hörnle and Huster 2013).

6 'Reasonable accommodation' refers to a technique designed in the first instance to meet the specific needs of persons with a handicap. Reasonable accommodation removes the barriers faced by people in the ordinary course of social interaction: in the labour market, at school, when entering public buildings, etc. There is no fixed list of what 'reasonable accommodations' may be possible. The decision must be made in each case, taking account of the specificities of the individual situation. Reasonable accommodation may consist of remediating measures (helping individuals); differential measures (laying down different conditions); compensatory measures (via compensation or extra resources); or exonerating measures (exemptions). In determining whether the accommodation is reasonable, the following are taken into consideration: the cost, the impact the accommodation would have both on the persons in question and on their immediate surroundings; whether or not there are equivalent alternatives. The technique lends itself to application to other minorities in society, with a view to enabling them to participate in the ordinary course of social interaction (including minority policy). The question that arises in this regard is whether, in the case of cultural, religious and/or ethnic minorities, for example, the application of the technique of reasonable accommodation can be made mandatory. Opinions vary greatly. On this issue and in particular on the question of the participation of members of a religious minority in the labour market, see the richly documented comparative study by Katayoun Alidadi (2017). See also, for a comparative law approach (Hendrickx and Roger 2016).

A few of these reactions are discussed in (Foblets 2016).

A similar criticism was made several years ago (Viens 2004, p. 242).

About this inconsistency, see (Levey 2013; Shweder 2013).

See, among others (Scolnicov 2011).

See, among others (Bergeaud-Blacker 2011; Lerner and Mordechai Rabello 2006; Foblets and Velaers 2013; Van der Schyff 2014; Hehemann 2019; UlAin and Whiting 2017).

12 Judgment of 17 December 2020, Centraal Israëlitisch Consistorie van België and Others, Case C 336/19 (see Press Release No 163/20); this judgment followed two previous rulings: the judgments of 29 May 2018, Liga van Moskeeën en Islamitische Organisaties Provincie Antwerpen and Others, C-426/16 (see Press Release No 69/18), and of 26 February 2019, Euvre d'assistance aux bêtes d'abattoirs, C-497/17 (see Press release No 15/2019). Council Regulation (EC) No 1099/2009 on the protection of animals at the time of killing (OJ 2009 L 303, 1).

14 See, among others (Bergeaud-Blacker 2011, op. cit., pp. 420-37; Foblets and Velaers 2013, op. cit., pp. 67-86; Van der Schyff 2014, op. cit., pp. 76-102).

See, among others (Elver 2014; Berghahn 2012; Howard 2013, 2014).

This debate is not limited to Europe. See (Korteweg and Yurdakul 2014).

See Note 3.

See Note 3.

OJ L. 2 December 2000, No 303, 0016-0022.

The Court made a connection here with the case law of the European Court of Human Rights in respect of Article 9 of the ECHR (ECHR 15 January 2013, CE:ECHR:2013:0115JUD004842010 (Eweida and others v. The United Kingdom, point 94). See, among others (Weiler 2017; Collins 2018; Hambler 2018; Hennette-Vauchez 2017; Marin Ais 2018; Howard 2017).

The protection of the employer's freedom of belief (either positive or negative) constitutes, of course, an issue in itself, and would deserve to be further explored. There are two aspects: some employers may indeed wish to affirm their (religious or philosophical) identity and reflect that in their choice of the staff who represent the company, with the risk that this could be grounds for exclusion of certain (potential) employees. But the opposite is also true: by extending to the private sector the concept of 'neutrality' as it applies to public services, companies are offered an argument to exclude, in particular members of communities who insist on their right to identify with a particular belief and claim the right to express it, also in the workplace. In some cases, this is precisely what companies are aiming at, namely to exclude the prospect of such claims. The latter strategy has been fiercely criticized by minorities, as they see this policy as excluding them not only from working in the public service but also in private companies, for example if they wear religious signs of symbols (Ufarte 2017; Gonzalez 2018; Gonzalez 2020). ECHR 15 January 2013, ECLI:CE:ECHR:2013:0115JUD004842010 (Eweida and others $v$. The United Kingdom).

See, among others (Mathieu 2012; Pastor 2019).

CJEU 15 July 2021 in C-804/18 (WABE) and CJEU 15 July 2021 in C-341/19 (MH Müller Handel).

26 For example, in view of the court, avoiding social conflict may constitute a genuine employer need as well as maintaining a neutral attitude toward clients. In addition, the employer must prove that, without the introduction of a neutrality policy, its freedom to do business would be affected as it would suffer pernicious consequences given the nature or context of its activities. In this regard, see (Tarlo 2013; Grigo 2015).

Already in the months before the judgments were handed down, authors were emphasising the importance and the stakes involved in the two cases. See among others (Jolly 2016). 
Another practice that has caused much ink to flow, for now mainly in English-speaking countries, is the use of religious mediators or arbitrators in conflicts under private law. See, among others (Shachar 2008; Eisenberg 2007; Bano 2017). Opinions are divided (for two very critical anlayses, see (Manea 2016; Wagner 2015)). Scholarly studies that have thoroughly examined the functioning of "religious arbitration" are still relatively scarce. The mistrust is, therefore, all the greater.

\section{References}

Alidadi, Katayoun. 2017. Religion, Equality and Employment in Europe: The Case for Reasonable Accommodation. Oxford: Hart Publishing. Bano, Samia, ed. 2017. Women, Mediation and Religious Arbitration: Thinking through Gender and Justice in Family Law Disputes. Waltham: Brandeis University Press.

Bergeaud-Blacker, Florence. 2011. New Challenges for Islamic Ritual Slaughter: A European perspective. In Islam in the West. Vol. 4: Politics and Law. Edited by David Westerlund and Ingvar Svanberg. London: Routledge, pp. 420-37.

Berghahn, Sabine. 2012. Legal Regulations: Responses to Muslim headscarf in Europe. In Politics, Religion and Gender. Framing and Regulating the Veil. Edited by Sieglinde Rosenberger. London: Routledge, pp. 97-115.

Bodenheimer, Alfred. 2012. Haut Ab! Die Juden in der Beschneidungsdebatte. Göttingen: Wallstein Verlag.

Collins, Philippa M. 2018. Covering up? Client Embarrassment, Neutral Intolerance and Wearing Headscarves at Work. Law Quarterly Review 134: 31-37.

Eisenberg, Avigail. 2007. Identity, multiculturalism and religious arbitration: The debate over Shari'a law in Canada. In Sexual Justice/Cultural Justice. Edited by Avigail Eisenberg. London: Routledge, pp. 211-230.

Elver, Hilal. 2014. The Headscarf Controversy: Secularism and Freedom of Religion. Oxford: Oxford University Press.

Foblets, Marie-Claire. 2016. The Body as Identity Marker. Circumcision of Boys Caught between Contrasting Views on the Best Interests of the Child. In The Child's Interests in Conflict. The Intersections between Society, Family, Faith and Culture. Edited by Maarit Jänterä-Jareborg. Cambridge: Intersentia, pp. 125-62.

Foblets, Marie-Claire. 2018. Recht, cultuur en individuele zelfbeschikking. In Interdisciplinariteit in Het Recht. Law and ... Bewegingen in Het Privaatrecht. Edited by Eric Dirix. (Jura Falconis Libri, 20). Antwerp: Intersentia, pp. 55-76.

Foblets, Marie-Claire, and Jan Velaers. 2013. Recent Discussions in Belgium and the Netherlands on Religious Freedom and the Slaughter of Animals without Prior Stunning. In Recht, Religion, Kultur. Festschrift für Richard Potz zum 70. Geburtstag. Edited by Brigitte Schinkele, René Kuppe, Stefan Schima, Eva M. Synek, Jürgen Wallner and Wolfgang Wieshaider. Vienna: Facultas, pp. 67-86.

Frankfurter Allgemeine Zeitung. 2012. Graumann: Ein unerhörter und unsensibler Akt. June 26. Available online: https://www. faz.net/aktuell/politik/urteil-zu-beschneidung-von-jungen-graumann-ein-unerhoerter-und-unsensibler-akt-11799759.html (accessed on 5 March 2021).

Germann, Michael. 2013. Die Verfassungsmässigkeit des Gesetzes über den Umfang der Personensorge bei einer Beschneidung des männliches Kindes vom 20.12.2012. Medizinrecht 7: 412-24. [CrossRef]

Gonzalez, Gérard. 2018. Régulation du port de signes religieux en entreprise. Revue du Droit des Religions 6. Available online: http:/ /journals.openedition.org/rdr/340 (accessed on 4 March 2021). [CrossRef]

Gonzalez, Gérard. 2020. La liberté européenne de religion à l'épreuve de la jurisprudence de la Cour de justice de l'Union européenne. Revue trimestrielle des droits de l'homme 31: 103-20.

Grigo, Jacqueline. 2015. Religiöse Kleidung: Vestimentaire Praxis Zwischen IDENTITÄT und Differenz. Bielefeld: Transcript Verlag.

Hambler, Andrew. 2018. Neutrality and Workplace Restrictions on Headscarves and Religious Dress: Lessons from Achbita and Bougnaoui. Industrial Law Journal 47: 149-64. [CrossRef]

Hehemann, Lena. 2019. Religious Slaughtering and Organic Labels: Oeuvre d'assistance aux bêtes d'abattoirs. European Papers 4: 297-305.

Hendrickx, Frank, and Blanpain Roger, eds. 2016. Reasonable Accommodation in the Modern Workplace: Potential and Limits of the Integrative Logics. Alphen aan den Rijn: Kluwer Law International.

Hennette-Vauchez, Stéphanie. 2017. Equality and the Market: The Unhappy Fate of Religious Discrimination in Europe. European Constitutional Review 13: 744-58. [CrossRef]

Hörnle, Tatjana, and Stefan Huster. 2013. Wie weit reicht das Erziehungsrecht der Eltern? JuristenZeitung 68: 328-39. [CrossRef]

Howard, Erica. 2013. Law and the Wearing of Religious Symbols: European Bans on the Wearing of Religious Symbols in Education. London: Routledge.

Howard, Erica. 2014. Islamic Veil Bans: The gender equality justification and empirical evidence. In The Experiences of Face Veil Wearers in Europe and the Law. Edited by Eva Brems. Cambridge: Cambridge University Press, p. 190.

Howard, Erica. 2017. Islamic Headscarves and the CJEU: Achbita and Bougnaoui. Maastricht Journal of European and Comparative Law 24: 348-66. [CrossRef]

Isensee, Josef. 2013. Grundrechtliche Konsequenz wider geheiligte Tradition. JuristenZeitung 68: 317-27. [CrossRef]

Jolly, Schona. 2016. Islamic headscarves and the workplace reach the CJEU: The battle for substantive equality. European Human Rights Law Review 6: 622-80.

Korteweg, Anna C., and Gokce Yurdakul. 2014. The Headscarf Debates: Conflicts of National Belonging. Redwood City: Stanford University Press. 
Kristiansen, Maria, and Aziz Sheikh. 2013. Legislation on male infant circumcision in Europe: A call to avoid paternalism and to promote evidence-based patient-centred care. Global Discourse: An Interdisciplinary Journal of Current Affairs and Applied Contemporary Thought 3: 342-47. [CrossRef]

Lerner, Pablo, and Alfredo Mordechai Rabello. 2006. The Prohibition of Ritual Slaughtering (Kosher Shechita and Halal) and Freedom of Religion of Minorities. Journal of Law and Religion 22: 1-62. [CrossRef]

Levey, Geoffrey Brahm. 2013. Thinking about Infant Male Circumcision after the Cologne Court Decision. Global Discourse: An Interdisciplinary Journal of Current Affairs and Applied Contemporary Thought 3: 326-31. [CrossRef]

Manea, Elham. 2016. Women and Shari'a Law: The Impact of Legal Pluralism in the UK. London: I.B. Tauris.

Marin Ais, José Rafael. 2018. Freedom of Religion in the Workplace v. Freedom to Conduct a Business, The Islamic Veil before the Court of Justice: M. Samira Achbita Case. European Papers 3: 409-17.

Mathieu, Chantal. 2012. Le respect de la liberté religieuse dans l'entreprise. Revue de Droit du Travail 1: 17-23.

Pastor, Relaño Eugenia. 2019. Religious discrimination in the workplace: Achbita and Bougnaoui. In EU Anti-Discrimination Law Beyond Gender. Edited by Uladzislau Belavusau and Kristin Henrard. Oxford: Hart Publishing, pp. 183-202.

Scolnicov, Anat. 2011. The Right to Religious Freedom in International Law. Between Group Rights and Individual Rights. London and New York: Routledge.

Shachar, Ayelet. 2008. Privatizing diversity: A cautionary tale from religious arbitration in family law. Theoretical Inquiries in Law 2: 573-607. [CrossRef]

Shweder, Richard A. 2013. The Goose and the Gander: The genital wars. Global Discourse 3: 348-66. [CrossRef]

Strack, Christophe. 2012. European rabbis deplore circumcision ruling. Deutsche Welle. July 11. Available online: https:/ www.dw. com/en/european-rabbis-deplore-circumcision-ruling/a-16088448 (accessed on 10 October 2021).

Tarlo, Emma. 2013. Islamic Fashion and Anti-Fashion: New Perspectives from Europe and North America. London: Bloomsbury.

Ufarte, Thomas. 2017. La liberté de conscience des salariés face au culte de la liberté d'entreprise prôné par la CJUE: Une nouvelle guerre de religion? La Revue des droits de l'homme. Available online: http:/ /journals.openedition.org/revdh/3056 (accessed on 4 March 2021).

UlAin, Qurat, and Terry L. Whiting. 2017. Is a 'Good Death' at the Time of Animal Slaughter an Essentially Contested Concept? Animals 7: 99. [CrossRef]

Van der Schyff, Gerhard. 2014. Ritual Slaughter and Religious Freedom in a Multilevel Europe: The wider importance of the Dutch case. Oxford Journal of Law and Religion 1: 76-102. [CrossRef]

Viens, Adrian M. 2004. Value Judgement, Harm and Religious Liberty. Journal of Medical Ethics 30: 241-47. [CrossRef]

Wagner, Joachim. 2015. Richter Ohne Gesetz. Islamische Paralleljustiz gefährdet unseren Rechtsstaat. Berlin: Ullstein.

Walter, Tonio. 2012. Der Gesetzentwirf zur Beschneidung-Kritik und strafrechtliche Alternative. JuristenZeitung 67: 1110-17. [CrossRef]

Weiler, Joseph, ed. 2017. Je suis Achbita! International Journal of Constitutional Law 15: 879-906. [CrossRef]

Wheeler, Robert, and Pat Malone. 2013. Male Circumcision. Risk versus Benefit. Archives of Disease in Childhood 98: 321-22. [CrossRef] 